\title{
Legal Education of Medical Students Based on Medical Disputes
}

\author{
Zhongshan Jin \\ School of public health and management, Hubei \\ University of Medicine, shiyan, China
}

\author{
Chen Wei */corresponding author \\ School of humanity, Hubei University of Medicine, \\ shiyan, China \\ E-mail: weichen2012@163.com
}

\begin{abstract}
This paper is aimed to solve the medical students' ability of legal knowledge to prevent and resolve medical disputes in the future medical practice. By using literature review method, this paper will focus on two aspects: one hand, how to correctly position the medical students' legal education objective and to develop effective plan and measures in China. on the other hand, how to improve the ability to prevent and resolve medical disputes for medical institutions and medical personnel. The final results, which can protect medical students from medical disputes as far as possible, are the following: i) it is necessary to develop multigrade law courses, including theory and practice in medical colleges . ii) guide medical students to participate in the specific medical legal disputes during the whole medical study career. iii) compulsory medical personnel to do medical malpractice law study.
\end{abstract}

Keywords- medical dispute; legal education; law course; multi-grade; law case;

\section{INTRODUCTION}

At present, the domestic research on the cultivation of medical students' legal quality is still lack. Wen Rijin et al. first recognized the legal education of medical students should be combined with the theory of socialism with Chinese characteristics, the cultivation of medical students, and the characteristics of medical students, then he advised to hold more judicial expert lectures, court and visit the prison, case teaching and other activities. All these detailed research results can be seen in his paper of "Improving the legal quality of medical students based on education form of 'three combination' and 'three development" [1]. In the paper of "The ways and measures of Legal quality education of medical students"[2], Feng-Yu Zhi systematically put forward how the medical colleges and universities to strengthen the legal quality of medical students, including the transformation of medical education ideas, construction of teaching staff, to build a scientific teaching system, improve teaching methods, to carry out the relevant academic and community activities, etc.. Then some other researchers study the legal education of medical students from the specific medicine domain, like Zhu Zhi's paper of " On the cultivation of the legal awareness of the medical students in obstetrics and Gynecology"[3]. Considering the characteristics of Obstetrics and Gynecology, she elaborated the necessity and measures of the cultivation of students' legal consciousness in the teaching of Obstetrics and gynecology, including strengthening the communication between doctors and patients, regulating the medical records, respecting the patient's privacy, etc.. Zhang-Min Jian wrote a paper to explain the connotation of the right of informed consent, the relationship of medical disputes and the methods and ways to cultivate the right of informed consent [4]. All these legal education of medical students can be summarized as the following points: neither increases the courses of law, nor hold the mock court, nor go to court seeing and listening. But when considering the numbers of courses and students, medical students with non-legal professional background, it is hard to carry out the above legal education advices in true practical medical teaching. Based on the actual situation of talent cultivation in most medical schools (especially local medical institutions) in China, this paper will focus on the improving the medical students' ability of legal knowledge to prevent and resolve medical disputes in the future medical practice. The final results are to find the way of improving the pertinence and application of medical students' legal education, and then to realize the balance and mutual promotion of the legal quality education of medical students, medical humanities education, medical skill education, and then improve the practical, long-term and scientific of the whole medical education.

\section{THE CURRENT SITUATION OF LEGAL EDUCATION IN LOCAL MEDICAL COLLEGES}

More and more evidences show that China's medical disputes rapidly grow in the last twenty years. There are two main reasons for the increase of medical disputes. First, benefited from the popularization of legal society concept and the enhancement of people's legal consciousness, people always consciously use the law to safeguard their own rights and interests when the disputes happen. Second, some medical staffs are still lack of necessary legal skills to protect themselves from the medical disputes, or in other words, they are lack of necessary skills to reduce the occurrence of medical disputes. These necessary legal skills include theoretical legal knowledge and practical legal measures, and in our opinion, since the current situation of legal education in local medical colleges are not so good, all the above skills can be strengthened through improving the legal education of medical students. 


\section{A. The teaching hours of legal courses are not scientific} in ordinary medical colleges

The first situation of legal education in local medical university is the teaching hours are not scientific setting at all. Theoretically, there are three main kinds of legal courses in medical university. One is compulsory public basic course, like public health law course, all the medical students must learn this course in their freshman year study. The other one is professional courses for some specific medical students, like health course for health management students and pharmacy. The final one is the elective courses for all medical students. The specific teaching hours of the above kinds of legal courses are not unique and just dependent on the choice of school teaching management. Take Hubei University of Medicine as an example, as the public health law course for all the medical students, there are total more than four forms teaching hours presented in the following table

TABLE I. THE DIFFERENT TEACHING HOURS OF HEALTHE LAW COURESE IN DIFFERENT MEDICAL SPECIALTY IN HBMU

\begin{tabular}{|c|c|}
\hline Medical specialty & $\begin{array}{c}\text { The teaching hours } \\
\text { of health law course }\end{array}$ \\
\hline $\begin{array}{c}\text { Nursing specialty } \\
\text { (Undergraduate Four- } \\
\text { years) }\end{array}$ & 26 \\
\hline $\begin{array}{c}\text { Nursing specialty } \\
\text { (Specialty Three- } \\
\text { years) }\end{array}$ & 22 \\
\hline $\begin{array}{c}\text { Clinical and Oral } \\
\text { medicine specialty }\end{array}$ & 24 \\
\hline $\begin{array}{c}\text { Pharmaceutical } \\
\text { specialty }\end{array}$ & 24 \\
\hline $\begin{array}{c}\text { Anesthesia and } \\
\text { Medical imaging } \\
\text { specialty }\end{array}$ & 24 \\
\hline $\begin{array}{c}\text { Institute of medicine } \\
\text { and nursing (including } \\
\text { all medical specialty) }\end{array}$ & 18 \\
\hline
\end{tabular}

The institute of medicine and nursing is an independent teaching unit share with the same teaching source, but it is also subordinated to the Hubei University of medicine. The teaching hours of the same health course are varied from 18 to 26 , the key reason is not from the scientific analysis, but just from the unbelievable reason of total limit teaching hours of the different specialties.

\section{B. Nearly all the medical students' legal courese are only studied in the freshman year}

The second situation of legal education in local medical university is nearly all the medical students study the law courses only in their freshman year. Still take the author's medical university for example, except the health management specialty students, all the other medical students only study the public health law course in their freshman year. No matter you are the four-years' undergraduate or the three-years college students, or no matter you are you are nursing or pharmacy major. As we all know that, the medical disputes must not happen in the students' freshman year! The practice period of medical students and hospital regulation period of medical graduates are the period most likely to see and experience the medical disputes. But after the freshman year study, the legal education is empty for nearly all the medical students. This will absolutely cause the medical students or medical graduates cannot use the law skills to dispose the medical disputes when they face the disputes. Furthermore, neither the medical students in the practice period, nor the medical graduates in the hospital regulation period, their medical skills teachers also have no law skill to dispose the above disputes. Imagining this cycle runs time after time, what will happen?

\section{The law teachers and books for different medical students are relatively simple}

The third situation of legal education in local medical university is that, all the medical students share with the same law teachers and same law books. This situation is the key obstacle to improving the quality of medical students' legal education. Medical students with different specialties need different law skills to deal with the same medical dispute. The most ordinary medical dispute will happen when the patients or the patients' families suspected that the doctor or the nurse has not taken the appropriate treatment or use a drug that is not conducive to the disease, which caused the patient's condition worse or even death. From the viewpoint of law, the different medical practitioners have different legal obligations. In china, the nurses have no right to prescribe medicine, and absolutely cannot decide the treatment plan. The nurse staff is only the executive of the medical plan and rehabilitation program. But the clinicians are different, they should determine the patient's disease and develop a treatment plan by some medical testing reports and their professional experiences. In other words, the clinicians take the legal responsibility of medical technology; the nurses take on the legal responsibility of nursing[5].

TABLE II. THE RELATED AREAS OF REPONSIBILITY OF DIFFERENT MEDICAL SPECIALTY

\begin{tabular}{|c|c|}
\hline Medical specialty & $\begin{array}{l}\text { Related areas of } \\
\text { responsibility }\end{array}$ \\
\hline Nursing & Nursing skills \\
\hline Clinical medicine & Clinical skills \\
\hline Oral medicine & Oral medical skills \\
\hline Pharmacy & Drug Administration \\
\hline Anesthesia & Anesthesia skills \\
\hline Medical imaging & Imaging report \\
\hline $\begin{array}{l}\text { Biochemical } \\
\text { examination }\end{array}$ & Biochemical test report \\
\hline Rehabilitation & $\begin{array}{c}\text { Rehabilitation treatment } \\
\text { skills }\end{array}$ \\
\hline
\end{tabular}

From the TABLE II, we can find that when the medical disputes happen, different medical staff naturally bear different legal responsibilities. But the different medical students have the same law teachers with the same books and teaching hours of law courses. Then, by the same teaching sources, no difference can occur. 


\section{LEGAL EDUCATION REFORMATION OF MEDICAL STUDENTS BASED ON THE MEDICAL DISPUTES IN LOCAL MEDICAL COLLEGES}

The purpose of this paper is to find a way to solve the problems presented in Section II. There are indeed existed some researches on the legal education of medical students, as we have claimed in Section I, neither the existed researches are too general about increasing the teaching hours of legal courses of medical students, nor they are too unrealistic to realize, like leading the medical students to attend medical dispute trial as much as possible. In this Section, we will find that the legal education reformation of medical students can be considerable if the law courses are based on concrete legal characteristics, like medical disputes. The legal characteristics of medical disputes will be first presented, and then combined with the conclusions of Section II, the legal education reformation of medical students based on the medical disputes will be discussed one by one.

\section{A. The legal characteristics of medical disputes}

Medical disputes are usually caused by medical negligence and negligence. Medical negligence is the failure of medical personnel in the process of diagnosis and nursing. Medical fault is the fault of medical personnel in medical activities such as medical care. These errors often result in the patient's dissatisfaction or cause to the patient's harm, and thus cause medical disputes. Additionally, although there are no mistakes did by doctors, the medical disputes can also happen if the patients are not satisfied by their thinking. Such disputes can be caused by lack of basic medical knowledge, the correct treatment of medical treatment, the natural outcome of the disease, and the complications that are difficult to avoid, and the unexpected accidents in medical treatment[6].

From the legal point of view, when the medical disputes happen, the doctors and patients can require the other party to take responsibility neither from the tort liability nor liability for breach of contract. Thus the legal characteristics of medical disputes can be divided into three parts: the civil disputes (civil compensation) in the civil law; administrative disputes (administrative punishment) in the administrative law; criminal liability (medical malpractice) in the criminal law [7-8]. Remember that the responsibility of both parties are the most important issues in the medical disputes.

For the legal education of medical students, health law course naturally contains the above three basic laws, but as we have claimed in the Section II, different medical specialties need different legal skills, and thus need to carefully determine the teaching hours and teaching contents.

\section{B. The teaching hours of medical students' legal courses based on the medical disputes}

How to scientifically determine the teaching hours of different medical students' legal courses is not a trivial question. But if the above problem is limited to medical disputes, we can give some standards of teaching hours. For medical students, the legal issues of medical disputes always focus on civil law and criminal law[9,10]. Combined with the different features of contents of the civil law and criminal law, when supposing the teaching hours of criminal law is $\alpha$ (variable quantity dependent on the total teaching contents), the teaching hours of civil law is approximately equal to $1.5 \alpha$, which means the total teaching hours of legal course is beta

$$
\beta \approx \alpha+1.5 \alpha=2.5 \alpha
$$

Eq. (1) is the conclusion of using the incomplete mathematical induction method to summarize the enough data of the existed teaching hours of civil law and criminal law courses in different universities. When casting the Eq. (1) into the TABLE I, we can find that the unit teaching hours are separately $\alpha \approx 10$ and $\alpha \approx 6$ in the Hubei University of medicine. But, since the different medical staffs bear different responsibilities, the Eq. (1) is not so exact to the different medical students. When introducing a parameter $\chi$, representing different medical specialties effects, we can revise the Eq. (1) as the following form

$$
\beta \approx 2.5 \alpha+\chi
$$

The corrective parameter $\chi$ is the most important work for this paper. This correction refers to the teaching contents changed with different specialties and teachers.

From the TABLE II, we can safely conclude that the teaching contents of different medical specialties' students must be different. The parameter $\chi$ in Eq. (2) reflects this difference, and thus needs more carefully study. The TABLE I shows this difference is just arranged in a small area, $-3 \leq \chi \leq+2$, approximately

$$
\chi \approx \pm \frac{1}{5} \alpha
$$

By analyzing the teaching hours of criminal law course in various universities, we can find that the $\alpha \approx 20$ is much more scientific than that $\alpha \approx 10$. Casting $\alpha \approx 20$ into Eq. (2) and using Eq. (3), we can get the following TABLE III TABLE III. THE RECALCULATION OF TEACHING HOURS OF HEALTH
LAW COURESE IN HBMU

\begin{tabular}{|c|c|}
\hline Medical specialty & $\begin{array}{c}\text { The teaching hours } \\
\text { of health law course }\end{array}$ \\
\hline $\begin{array}{c}\text { Nursing specialty } \\
\text { (Undergraduate Four- } \\
\text { years) }\end{array}$ & 51 \\
\hline $\begin{array}{c}\text { Nursing specialty } \\
\text { (Specialty Three- } \\
\text { years) }\end{array}$ & 47 \\
\hline $\begin{array}{c}\text { Clinical and Oral } \\
\text { medicine specialty }\end{array}$ & 49 \\
\hline $\begin{array}{c}\text { Pharmaceutical } \\
\text { specialty }\end{array}$ & 49 \\
\hline $\begin{array}{c}\text { Anesthesia and } \\
\text { Medical imaging } \\
\text { specialty }\end{array}$ & If considering the third part of medical disputes, \\
conts
\end{tabular}
administrative disputes (administrative punishment) in the administrative law, we can safely conclude that the total teaching hours should be increased in TABLE III. 


\section{The multi-grade and multi-time period legal education for all medical students based on the medical disputes}

The B part of Section II tells us that the only one-year or one-term study of legal courses cannot help medical students dealing with the medical disputes . Based on the medical disputes' characteristics, the multi-grade and multi-time period legal education for all medical students are useful. The concrete method can be seen in the TABLE IV . The most important study in junior or practice period in the hospital needs much more teaching attention, since these studies always taught by lawyers in law office or some experienced doctors in the concrete department in the hospital.

TABLE IV. MULTI-GRADE LEARNING LAW OF MEDICAL STUDENTS

\begin{tabular}{|c|c|}
\hline Study year & Law course \\
\hline Freshman year & Basic law course \\
\hline $\begin{array}{c}\text { Junior to senior for } \\
\text { clinic medicine }\end{array}$ & $\begin{array}{c}\text { Classroom learning } \\
\text { law of medical disputes }\end{array}$ \\
\hline Practice period & $\begin{array}{c}\text { Department study law } \\
\text { of medical disputes }\end{array}$ \\
\hline
\end{tabular}

\section{The resourceful of law teachers}

The legal literacy of students in medical colleges always decided by the law teachers. In order to improve the medical students' ability of dealing with the medical disputes, the law teachers' ability of dealing with the concrete medical dispute is absolutely the most important aspect. So the various experienced lawyers in medical disputes will be invited to hospital to give some lessons of law courses to medical students. On the one hand, inviting the famous lawyers give the concrete law lessons can solve the simple law teacher to the different medical students. On the other hand, the hospital can afford the expense cost for those famous lawyers. Combining with the first-year law course study, we can find that after the lawyers lessons in hospital. the ability of dealing with the medical disputes will be improved more and more.

\section{SUMMARY}

In this paper, firstly, we introduced the current situation of legal education is not so good, and thus needs to improve further. Then, we summarized the legal characteristics of medical disputes, and developed the scientific teaching hours of legal courses in medical colleges, multi-grade study and enrich the law teachers source based on the medical disputes. Finally, we believe that the legal education teaching based on the characteristics of medical disputes will absolutely improve the legal quality of all the medical students.

\section{ACKNOWLEDGMENT}

This work is supported by the 2012 teaching research project of Hubei University of medicine of Institute of medicine and nursing, No. YHJ201202.

\section{REFERENCES}

[1] Wen Rijin et al,T Improving the legal quality of medical students based on education form of 'three combination' and 'three development, Journal of Guangxi Traditional Chinses medical university, 2001(18).

[2] Feng-Yu Zhi, The ways and measures of Legal quality education of medical students, Journal of Liaoning Medical University: Social Science Edition, 2007 (1):12-14.

[3] Zhu Zhi, On the cultivation of the legal awareness of the medical students in obstetrics and gynecology, Journal of Northwest Medical Education,2011 (6):1179-1181.

[4] Zhang-Min Jian, Cultivation of medical students' awareness of the right to know. Journal of Shanxi Medical University(Preclinical Medical Education Edition), 2005 (5): 555-557.

[5] DL Rhode, Legal Education: Rethinking the Problem, Reimagining the Reforms, Pepperdine Law Review's April 20, 2012.

[6] S Peter, The Legal Education-Legal Practice Relationship: A Critical Evaluation, 2015 CEPLER Working Paper Series.

[7] R Rubinson, The Holmes School of Law: A Proposal to Reform Legal Education Through Realism. (2014), unprint..

[8] K Lachmayer, J Busch, J Kelleher, G Turcanu, Constitutional Law in Legal Education, Phys. Rev. D 85, 023533(2014).

[9] X Arzoz, KF Gómez, SI Strong, Review Essay-Bilingual Legal Education in the United States: An Idea Whose Time Has Come? Journal of Legal Education (2014) :354-362.

[10] JP White, State Supreme Courts as Regulators of the Profession Part I: Supreme Courts and Legal Education Reform, Notre Dame Law Review, 2014, Vol 72, Issue 7: 1155-1168. 